\title{
Chestnut Response to Organo-mineral and Controlled-Release Fertilizers in Rainfed Growing Conditions
}

\author{
Manuel Ângelo Rodrigues ${ }^{1}$ (D) Vagner Grade $^{2} \cdot$ Valdemar Barroso $^{3} \cdot$ Abel Pereira $^{4} \cdot$ Luís César Cassol $^{2}$. \\ Margarida Arrobas ${ }^{1}$ (D)
}

Received: 5 July 2019 / Accepted: 16 October 2019

(C) Sociedad Chilena de la Ciencia del Suelo 2019

\begin{abstract}
In the context of climate change, chestnut fertilization is receiving great attention in the Mediterranean basin, due to the increase in the unpredictability of the pluviometric regime which makes it difficult to determine the optimal timing of fertilizer applications. The purpose of this work was to assess the suitability of fertilizers with mechanisms for nutrient protection on the increase of tree nutritional status and crop productivity. Four fertilizers with restricted nutrient solubility were tested: Bioscape 5:14:7 (32.8\% organic matter (OM)); Humix 13:3:5 (80.1\% OM); Exactyon AG 6:15:8 (37.7\% N and 33.1\% P encapsulated); and Exactyon AG 18:5:13 (47\% N encapsulated, $28.8 \% \mathrm{~N}$ as urea coated with ammonium sulfate). The trials were carried out for four years in Moimenta and Meixedo, NE Portugal, which also received a non-fertilized control. In Moimenta the ground was managed by tillage and in Meixedo by a cover of natural vegetation. Exactyon AG 18:5:13, being the most concentrated in $\mathrm{N}$ and B, gave significantly higher cumulative (2015-2018) nut yields $\left(146.6 \mathrm{~kg} \mathrm{tree}^{-1}\right)$ than the control $\left(52.3 \mathrm{~kg} \mathrm{tree}^{-1}\right)$ in the Moimenta trial. The results were explained by the increase in leaf $\mathrm{N}$ and $\mathrm{B}$ levels, which in the control treatment were in the deficiency range. In Meixedo there were not found significant differences among treatments, likely due to the competition by cover crop for resources. The results showed that the response of the trees to the fertilizers relied mainly in their content in nutrients limiting to the agroecosystem and less in the mechanisms of nutrient protection.
\end{abstract}

Keywords Castanea sativa $\cdot$ Nut yield $\cdot$ Crop removal $\cdot$ Crop nutritional status $\cdot$ Fertilizers

\section{Introduction}

Chestnut (Castanea sativa Mill.) has gained remarkable importance in recent years for fruit production in some countries of the Mediterranean basin (Martins et al. 2011; ÁlvarezÁlvarez et al. 2010). The species has several phytosanitary problems, which can severely reduce crop productivity. The most important are chestnut ink (Phytophthora cinnamoni

Manuel Ângelo Rodrigues

angelor@ipb.pt

Vagner Grade

gradevagner@gmail.com

Valdemar Barroso

csb01.pt@atlanlusi.com

Abel Pereira

abel.arborea@gmail.com

Luís César Cassol

cassol@utfpr.edu.br
Rand and P. cambivora (Petri) Buisman) (Maurel et al. 2001; Gouveia et al. 2005), chestnut blight (Cryphonectria parasitica (Murrill) Barr.) (Murolo et al. 2019), and the invasive gall wasp (Dryocosmus kuriphilus Yasumatsu) originating in Asia (Gençer and Mert 2019). However, the recognition of the high nutritional value of the nuts and by-products (Borges et al. 2008; Echegaray et al. 2018) has raised the price of chestnut, which has led farmers to invest in the species.

Margarida Arrobas marrobas@ipb.pt

1 Centro de Investigação de Montanha (CIMO), Instituto Politécnico de Bragança, Campus de Santa Apolónia, 5300-253 Bragança, Portugal

2 Universidade Tecnológica Federal do Paraná, Campus Dois Vizinhos, Paraná, Brazil

3 Atlanlusi Europe, Lda., Batalha, Portugal

4 ARBOREA, Associação Agro-Florestal e Ambiental da Terra Fria Transmontana, Vinhais, Portugal 
Having said that, there are only limited areas in the mountainous regions of southern Europe where chestnut can be grown.

In the past, chestnut was grown as isolated trees, small orchards, or mixed stands in agro-forestry systems, receiving reduced attention. Nowadays, chestnut trees are being planted just like other fruit tree species in true orchards and denser plantations (Martins et al. 2011). The application of fertilizer is also widespread among farmers (Arrobas et al. 2018). Producers have intensified the cultivation processes to improve the nut production of the healthy trees and to try to compensate for yield reduction caused by pests and diseases. Although there are few studies on chestnut fertilization, in comparison with the more widespread fruit species, those already done have highlighted the relevant role of $\mathrm{B}$ (Portela et al. 2011, 2015; Arrobas et al. 2017), K (Arrobas et al. 2017), and $\mathrm{N}$ (Arrobas et al. 2018) in the nutrition of chestnut trees.

Chestnut is cultivated in mountainous areas of southern Europe. Although at high altitude the rains are more abundant, in the highlands the terrain is slope and there is no infrastructure for irrigation. In rainfed conditions, the growing season is short, limited in winter by frost and in summer by scarce rains and reduced soil water availability. Furthermore, in a Mediterranean climate the precipitation in spring is highly irregular, which makes it difficult to establish a fertilization program for the crop, and in particular to set the best timing for the application of fertilizers. In rainfed Mediterranean fruticulture, the most recommended practice is to apply the fertilizers at the end of the winter when most of the precipitation has already fallen, which reduces the risk of nutrient losses due to nitrate leaching and denitrification (FernándezEscobar 2017; Arrobas et al. 2019). A later application would be safer from this perspective, but may limit the absorption of nutrients due to soil dryness, since ion movements by mass flow and diffusion may be restricted (Havlin et al. 2014). In the context of climate change it is also expected that the unpredictability of the climate will increase (Crame et al. 2018) which may reduce nutrient use efficiency.

The use of fertilizers that release nutrients gradually can increase the opportunity for plant nutrient uptake and reduce the losses to the environment. Fertilizers which delay the time of nutrient availability may reduce the risk of being lost by leaching following a period of high precipitation. Organic materials, releasing the nutrients gradually, following a process of mineralization by soil microorganisms, have such properties (Olk 2008). Fertilizers with other mechanisms that restrict nutrient availability, such as slow-release, controlledrelease, and stabilized fertilizers, have also been developed to enhance nutrient use efficiency in agroecosystems that pose great challenges for nutrient management (Trenkel 2010; Arrobas et al. 2011; Zhang et al. 2019).

In this work, fertilizers with organic components and controlled-release fertilizers were tested in rainfed managed chestnut orchards in a climate characterized by high irregularity of precipitation during the spring. The use of controlled-release fertilizers is not common in rainfed fruticulture, whereas the use of organo-mineral fertilizers is very usual, although rarely included in fertilization studies. The fertilizers were applied in mid-March, slightly earlier than recommended for the conventional mineral fertilizers. Four fertilizers of different natures and nutrient concentrations were applied at the same rates in two mature chestnut orchards. It is hypothesized that these fertilizers with mechanisms for nutrient protection will be effective in increasing the tree nutritional status and crop productivity.

\section{Materials and Methods}

\subsection{Characterization of the Experimental Plots}

The field trials were conducted in the region of Bragança, Northeast of Portugal, namely in Moimenta (41.947937 $7^{\circ},-$ $\left.7.000199^{\circ}\right)$ and Meixedo $\left(41.850442^{\circ},-6.683273^{\circ}\right)$. Bragança benefits from a Mediterranean climate with some Atlantic influence. The mean air temperature and the annual precipitation (1980-2010) were respectively $12.7^{\circ} \mathrm{C}$ and $772.8 \mathrm{~mm}$. The average monthly air temperature and precipitation recorded during the four years of study are shown in Fig. 1.

The soil of the orchard in Moimenta is an umbric Cambisol derived from granite. The texture is sand, with $88.4 \%$ sand, $9.8 \%$ silt, and $1.8 \%$ clay. The orchard of Meixedo is planted in an umbric Leptosol derived from basic rocks. The soil is a loamy-sand textured with $72.4 \%$ sand, $21.0 \%$ silt, and $6.6 \%$ clay. Several other soil properties found in samples $(0-0.2 \mathrm{~m}$ depth) collected at the time of the initiation of the trials are shown in Table 1.

\subsection{Experimental Designs and Characterization of the Fertilizers}

The orchards of Moimenta and Meixedo were, respectively, 25 and 20 years old at the time of installation of the trials. The trees showed a lack of homogeneity in the size of the canopy. Thus, the experiments were arranged as randomized block designs. Three groups of five particularly homogeneous trees within the group were selected to form three blocks. The trees were subsequently numbered. The fertilizer treatments were randomly distributed within each block. Each tree constituted an experimental unit.

Five treatments were imposed, namely four compound NKP fertilizers which macronutrients are expressed as N, $\mathrm{P}_{2} \mathrm{O}_{5}$, and $\mathrm{K}_{2} \mathrm{O}$, and a control treatment without fertilization. The fertilizers were provided by Atlanlusi Europe, Lda., and they are on the market under the trade names Bioscape 5:14:7, 
Fig. 1 Monthly precipitation and average monthly temperature recorded in the meteorological station of Bragança during the four years of study

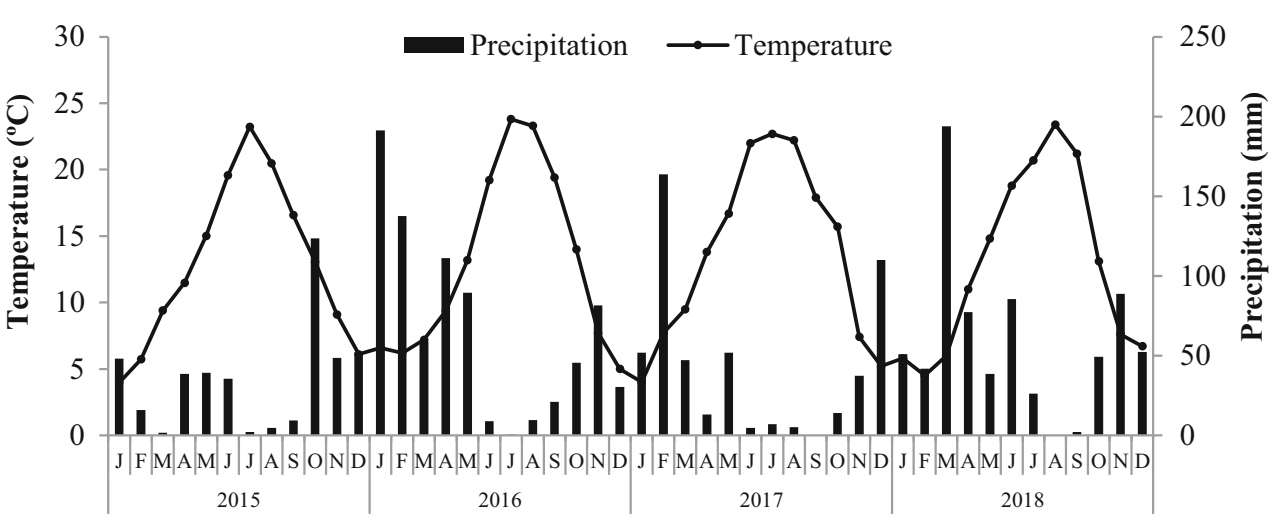

Since it was decided to use fertilizers with different mechanisms of nutrient protection, those available on the market present different concentrations of $\mathrm{N}, \mathrm{P}$, and $\mathrm{K}$, which did not allow the use of the same amount of N, P, and $\mathrm{K}$ in all treatments. All the fertilizers were used at the rate of $3 \mathrm{~kg}$ per tree (the farmers usually use 2 to $4 \mathrm{~kg}$ per tree). The trees are spaced at $8 \times 8 \mathrm{~m}$. This means that a different amount of each nutrient was supplied with each commercial product. Fertilizing units $\left(\mathrm{N}: \mathrm{P}_{2} \mathrm{O}_{5}: \mathrm{K}_{2} \mathrm{O}\right)$ were 23:66:33, 61:14:23, 28:70:37, and 84:23:61 $\mathrm{kg} \mathrm{ha}^{-1}$, respectively, for Biocaspe 5:14:7, Humix 13:3:5, Exactyon AG 6:15:8, and Exactyon AG 18:5:13. The fertilizers were applied beneath the canopies of the trees in the middle of March in 2015, 2016, 2017, and 2018. In Moimenta the fertilizers were incorporated into the soil with a cultivator which simultaneously destroyed the weeds. This operation was repeated 2 months later for a second control of weeds. In Meixedo the fertilizers were spread on the ground but not incorporated into the soil. Here the farmer manages the ground with a cover of natural vegetation mowed once or twice during spring.

\subsection{Soil Testing and Plant Analysis}

At the initiation of the field trials, composite samples of soils were collected at $0-0.2 \mathrm{~m}$ depth to characterize the experimental plots. The results are presented in Table 1. At the end of the experiments, in November 2018, composite soil samples were

(EA) and effective cation exchange acidity (CECe) from soil samples taken just before the installation of the field trials
Table 1 Organic carbon (OC), $\mathrm{pH}\left(\mathrm{H}_{2} \mathrm{O}\right)$, extractable phosphorus (P), potassium $(\mathrm{K})$, and boron $(\mathrm{B})$; exchangeable calcium $\left(\mathrm{Ca}^{2+}\right)$, magnesium $\left(\mathrm{Mg}^{2+}\right)$, potassium $\left(\mathrm{K}^{+}\right)$, and sodium $\left(\mathrm{Na}^{+}\right)$; and exchangeable acidity

\begin{tabular}{|c|c|c|c|c|c|c|c|c|c|c|c|}
\hline \multirow[t]{3}{*}{ Site } & \multirow{3}{*}{$\begin{array}{l}\mathrm{OC}^{1} \\
\mathrm{~g} \mathrm{~kg}^{-1}\end{array}$} & \multirow{3}{*}{$\begin{array}{c}\mathrm{pH} \\
\mathrm{H}_{2} \mathrm{O}\end{array}$} & \multicolumn{3}{|c|}{ Extractable } & \multicolumn{6}{|c|}{ Exchangeable complex ${ }^{4}$} \\
\hline & & & \multirow{2}{*}{$\begin{array}{l}-\mathrm{P}^{2} \\
\mathrm{mg} \mathrm{kg}^{-1}\end{array}$} & \multirow[t]{2}{*}{$\mathrm{K}^{2}$} & \multirow[t]{2}{*}{$\mathrm{B}^{3}$} & \multirow{2}{*}{$\begin{array}{l}\mathrm{Ca}^{2+} \\
\mathrm{cmol}+\mathrm{kg}^{-1}\end{array}$} & \multirow[t]{2}{*}{$\mathrm{Mg}^{2+}$} & \multirow[t]{2}{*}{$\mathrm{K}^{+}$} & \multirow[t]{2}{*}{$\mathrm{Na}^{+}$} & \multirow[t]{2}{*}{ EA } & \multirow{2}{*}{ CECe } \\
\hline & & & & & & & & & & & \\
\hline Moimenta & 12.5 & 4.8 & 89.5 & 120.3 & 0.6 & 0.8 & 0.4 & 0.6 & 1.1 & 1.3 & 4.2 \\
\hline Meixedo & 10.2 & 6.0 & 80.8 & 147.7 & 1.0 & 7.1 & 0.6 & 0.5 & 0.6 & 0.8 & 9.6 \\
\hline
\end{tabular}

\footnotetext{
${ }^{1}$ Walkley-Black. ${ }^{2}$ Ammonium lactate. ${ }^{3}$ Hot water, azomethine-H. ${ }^{4}$ Ammonium acetate for bases and potassium chloride for exchangeable acidity (EA) from which effective cation exchange capacity (CECe) was estimated
} 
Table 2 Composition of the fertilizers used in the experiments as appears on packaging label

\begin{tabular}{lllll}
\hline & Bioscape 5:14:7 & Humix 12:3:5 & Exactyon 6:15:8 & Exactyon 18:5:13 \\
\hline Organic matter $(\%)$ & 32.8 & 80.1 & 3.2 & 0 \\
Nitrogen $(\%)$ & 5 & 12 & 6 & 18 \\
Phosphorus $\left(\%, \mathrm{P}_{2} \mathrm{O}_{5}\right)$ & 14 & 3 & 8 & 5 \\
Potassium $\left(\%, \mathrm{~K}_{2} \mathrm{O}\right)$ & 7 & 5 & 15.1 & 13 \\
Calcium $(\%)$ & 18.0 & 1.2 & 1.0 & 2.5 \\
Magnesium $(\%)$ & 0.2 & 0.4 & - & 2.0 \\
Boron $\left(\mathrm{mg} \mathrm{kg}^{-1}\right)$ & - & 31 & 4 & 2011 \\
Cooper $\left(\mathrm{mg} \mathrm{kg}^{-1}\right)$ & - & - & 6000 & 2 \\
Iron $\left(\mathrm{mg} \mathrm{kg}^{-1}\right)$ & 136 & 332 & 119 & 2600 \\
Zinc $\left(\mathrm{mg} \mathrm{kg} \mathrm{k}^{-1}\right)$ & 15 & 36 & 600 & 51 \\
Manganese $\left(\mathrm{mg} \mathrm{kg}^{-1}\right)$ & 36 & 89 & & 200 \\
\hline
\end{tabular}

also collected at three depths $(0-0.1 \mathrm{~m}, 0.1-0.2 \mathrm{~m}$, and $0.2-$ $0.3 \mathrm{~m}$ ) to evaluate the effect of fertilizers on several parameters of soil fertility.

After drying $\left(40{ }^{\circ} \mathrm{C}\right)$ and sieving (2-mm mesh), the soil samples of the two field trials were submitted to analytical determinations: (1) $\mathrm{pH}\left(\mathrm{H}_{2} \mathrm{O}, \mathrm{KCl}\right)$; (2) easily oxidizable carbon $(\mathrm{C})$ determined by the Walkley-Black method and total organic $\mathrm{C}$ by incineration; (3) cation exchange capacity (ammonium acetate, $\mathrm{pH} 7.0$ ); (4) extractable $\mathrm{P}$ and $\mathrm{K}$ (ammonium lactate); (5) extractable B (azomethine-H); and (6) acid phosphatase activity determined from the conversion of $\mathrm{p}$ nitrophenyl phosphate to p-nitrophenol. In the initial samples there were also determined (7) clay, silt, and sand fractions by the Robinson pipette method. Methods 1-5 and 7 are fully described by Houba et al. (1997) and method 6 by Alef et al. (1995).

In summer, in late July, leaf samples were collected to assess the effect of the treatments on plant nutritional status. At harvest samples of nuts were also taken for elemental analysis to allow the estimation of the recovery of nutrients by the crop. Tissue samples (leaves and nuts) were oven-dried at $70{ }^{\circ} \mathrm{C}$ and ground. Thereafter, they were digested with nitric acid in a microwave (MARSXpress, CEM). N was determined by Kjeldahl (FOSS Kjeltec ${ }^{\mathrm{TM}} 8400$ ), B and P by colorimetry (GENESYS 6 thermospectronic), K by flame emission spectrometry (Perkin Elmer Pinaacle 900T), and calcium $(\mathrm{Ca})$, magnesium $(\mathrm{Mg})$, copper $(\mathrm{Cu})$, iron $(\mathrm{Fe})$, zinc $(\mathrm{Zn})$, and manganese $(\mathrm{Mn})$ by atomic absorption spectrophotometry (Perkin Elmer Pinaacle 900T).

\subsection{Data Analysis}

Data analysis was carried out using JMP® 14 software. Firstly, data was tested for normality and homogeneity of variances using the Shapiro-Wilk test and Bartlett's test, respectively. The comparison of the effect of the fertilizer treatments was provided by ANOVA. When significant differences were found $(\alpha<0.05)$, the means were separated by the multiple range Tukey HSD test $(\alpha=0.05)$. To facilitate the interpretation of results and for graphical representation purposes, in some situations the mean confidence intervals $(\alpha=0.05)$ were also estimated.

\section{Results}

\subsection{Yield and Nutrient Removal in the Nuts}

The accumulated net yields (2015-2018) differed significantly between the control $\left(52.3 \mathrm{~kg}\right.$ tree $\left.{ }^{-1}\right)$ and the treatment Exactyon AG 18:5:13 (146.6 $\left.\mathrm{kg}^{-1} \mathrm{tre}^{-1}\right)$ in the experiment of Moimenta (Fig. 2). Among fertilized treatments no significant differences in nut yields were found, although the highest average value was recorded in the trees treated with Exactyon AG 18:5:13. In the Meixedo experiment there were not found significant differences among treatments in the annual productions or in the accumulated total.

No significant differences were found in the concentration of the macro- and micronutrients analyzed in the nut. The concentrations of nutrients were also in the same range of magnitude between sites except for Mn for which the higher values were found in the experiment of Meixedo. Thus, the results were presented as the range of variation found in all the treatments independent of site (Table 3 ). If the average value is multiplied by the productivity of the orchard (expressed as dry matter) the removal of each nutrient is obtained.

\subsection{Leaf Nutrient Concentrations}

The concentrations of the macronutrients $\mathrm{N}, \mathrm{P}$, and $\mathrm{K}$ in the leaves are shown in Fig. 3. In Moimenta, leaf $\mathrm{N}$ concentrations significantly differed among treatments on three of the four sampling dates. The higher values were found in the trees fertilized with Exactyon AG 18:5:13. With the exception of 
the values of Exactyon AG 18:5:13, the others were usually found close to, or below, the lower limit of the sufficiency range established for this species. In the trial of Meixedo, significant differences among treatments in leaf $\mathrm{N}$ concentration were only found in two samplings. The average values were found close to, or below, the lower limit of the sufficiency range. Leaf $P$ fell within the sufficiency range for all the treatments and sites. In Moimenta significant differences in leaf $\mathrm{P}$ concentration were observed in two of the four years of the trial. No significant differences in leaf $P$ concentrations were found in the Meixedo trial. Leaf K concentration greatly varied between years as is usual for $\mathrm{K}$ in fruit trees. Differences between treatments were found in three and two years, respectively, in Moimenta and Meixedo. In general, leaf $\mathrm{K}$ concentrations were found within the sufficiency range established for chestnut.

Leaf $\mathrm{Ca}$ concentrations differed among treatments in two and one years, respectively, in the Moimenta and Meixedo trials (Fig. 4). Exactyon AG 6:15:8 and Bioscape 5:14:7 usually presented the higher average values. Leaf $\mathrm{Ca}$ concentrations were usually found within the sufficiency range of the species. Significant differences among treatments were also found in three a7nd one year in leaf $\mathrm{Mg}$ concentrations. In Moimenta, the higher values were usually found in the trees treated with Exactyon AG 6:15:8. Leaf B concentrations significantly varied among treatments for all sampling dates at the two sites. The trees treated with Exactyon AG 18:5:13 displayed the higher values. Leaf B concentrations were usually found within the sufficiency range, except for the control treatment of the Moimenta trials where leaf B levels were found in the deficient range.

Leaf concentrations of the micronutrients $\mathrm{Fe}, \mathrm{Zn}, \mathrm{Cu}$, and $\mathrm{Mn}$ are presented in Table 4. The results over the years were quite similar, whereas only the data from the first (2015) and the last (2018) years are presented. Leaf $\mathrm{Fe}$ levels were of the same order of magnitude in the two sites and they fell within the sufficiency range. In Meixedo the average values in the control treatment were the lowest and significantly different from those of some fertilized treatments. Leaf $\mathrm{Zn}$ concentrations also fell within the sufficiency range, and when significant differences were found the lower average values were associated with the control treatment. Leaf copper concentrations were found within the sufficiency range but close to the lower limit. Significant differences among treatments were only found in 2015 in the Moimenta orchard. Leaf Mn concentrations were usually high, and in the Meixedo trial they were often above the higher limit of the sufficiency range (range of potential toxicity). Humix 13:3:5 and Exactyon AG 6:15:8 were usually associated with the higher leaf $\mathrm{Mn}$ concentrations.

\subsection{Soil Analyses}

Soil $\mathrm{pH}$ did not significantly change among treatments in any of the sites (data not shown). In Moimenta $\mathrm{pH}\left(\mathrm{H}_{2} \mathrm{O}\right)$ varied between 5.01-5.18, 4.86-5.17, and 4.81-5.14, respectively, in $0-0.1-\mathrm{m}, 0.1-0.2-\mathrm{m}$, and $0.2-0.3-\mathrm{m}$ soil layers. In Meixedo $\mathrm{pH}\left(\mathrm{H}_{2} \mathrm{O}\right)$ varied between 6.32-6.90, 5.38-5.82, and 5.065.26 from the surface to the deeper layers.

In Moimenta, soil organic $\mathrm{C}$ did not significantly vary among fertilizer treatments (Table 5). However, the average values of the control treatment were lower than the values found in the fertilized treatments in the $0-0.1-\mathrm{m}$ and $0.1-0.2-\mathrm{m}$ soil layers. In the $0-0.1-\mathrm{m}$ and $0.1-0.2-\mathrm{m}$ soil layers the values varied between 13.0 to $17.1 \mathrm{~g} \mathrm{~kg}^{-1}$ and 12.3 to $14.5 \mathrm{~g} \mathrm{~kg}^{-1}$. In Meixedo, soil organic $\mathrm{C}$ in the surface layer was significantly lower in the control $\left(15.8 \mathrm{~g} \mathrm{~kg}^{-1}\right)$ in comparison with the fertilized treatments $\left(>19.9 \mathrm{~g} \mathrm{~kg}^{-1}\right)$. In the $0.1-0.2-\mathrm{m}$ soil layer, the control treatment presented the lower average values of soil organic $\mathrm{C}\left(6.8 \mathrm{~g} \mathrm{~kg}^{-1}\right)$ but without significant difference for the fertilized treatments. In the $0.2-0.3-\mathrm{m}$ layer soil organic $\mathrm{C}$ varied between 4.7 and $5.9 \mathrm{~g} \mathrm{~kg}^{-1}$ without differences among treatments.

In Moimenta there were found significant differences among treatments in extractable $\mathrm{P}$ at all soil depths (Table 6). The control treatment always gave the lower average values. In Meixedo, significant differences in extractable $\mathrm{P}$ among treatments were only found in the $0-0.1-\mathrm{m}$ soil layer. The lower and higher values were respectively found in control and Bioscape 5:14:7 treatments. In Moimenta soil P levels decreased progressively with soil depth. In Meixedo this decrease was particularly marked between the $0-0.1-\mathrm{m}$ and the $0.1-0.2-\mathrm{m}$ soil layers in the fertilized treatments. The decrease between the layers $0.1-0.2-\mathrm{m}$ and $0.2-0.3-\mathrm{m}$ was still evident but less pronounced.

In Moimenta there were not found significant differences among treatments in acid phosphatase activity. There was observed a small decrease in acid phosphatase activity with depth. In Meixedo there were found significant differences among treatments at depths $0-0.1 \mathrm{~m}$ and $0.1-0.2 \mathrm{~m}$. The control treatment always showed the lower average values, but among fertilized treatments those that registered higher values in the surface layer were not the same registering the higher values in the layer $0.1-0.2 \mathrm{~m}$. The decrease in acid phosphatase activity with depth was more pronounced in Meixedo than in Moimenta.

Soil K levels extracted by ammonium lactate significantly differed among fertilizer treatments in the Moimenta trial in the $0-0.1-\mathrm{m}$ and $0.2-0.3-\mathrm{m}$ soil layers (Table 7). The control treatment gave the lower results. In Meixedo there were only found significant differences among treatments in the surface $0-0.1-\mathrm{m}$ layer. Soil K levels decreased along the soil profile in both 
Fig. 2 Annual and accumulated nut yield after four consecutive harvests as a function of fertilizer treatment. Letters above the columns are the result of analysis of variance and Tukey HSD test $(\alpha=0.05)$ for accumulated nut yield. No significant differences were found within each year
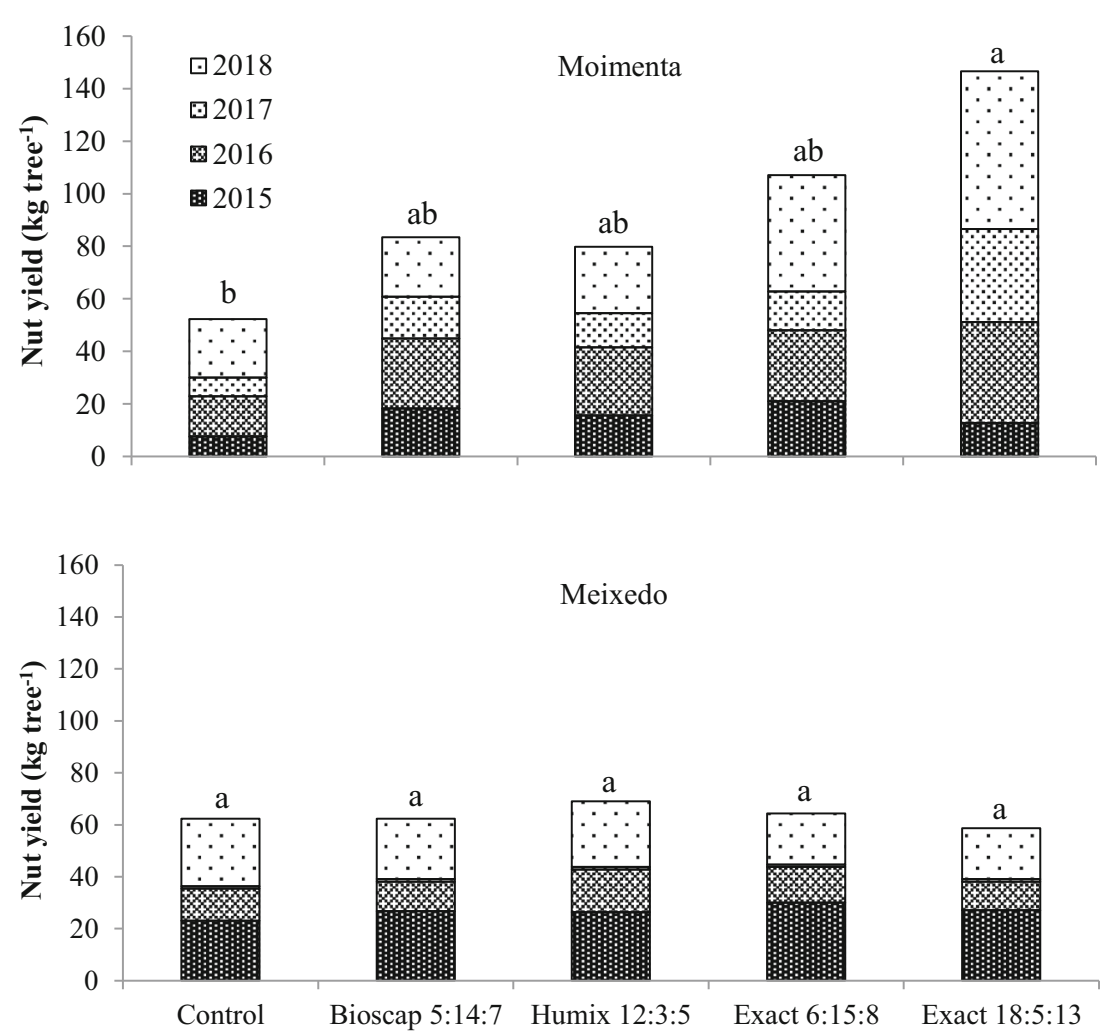

sites. Soil K levels extracted by ammonium lactate did not significantly vary among treatments in Moimenta. In Meixedo, in the surface layer, the average value found in the control treatment was significantly lower than those found in the fertilized treatments.

The results of the determination of exchangeable bases and exchangeable acidity, including $\mathrm{Ca}$ and $\mathrm{Mg}$, did not vary among treatments for any of the depths or localities (data not shown). The values of $\mathrm{Ca}$ and $\mathrm{Mg}$ were, however, much higher in Meixedo than in Moimenta.

Soil B levels showed significant differences among treatments at all soil depths of the Moimenta and Meixedo trials (Table 8). The Exactyon AG 18:5:13 treatment yielded the higher values very consistently at all depths and locations and always significantly higher than those of the control treatment. The B levels in the soil decreased with depth at both sites and were particularly high in the surface layer of the Meixedo trial.

\section{Discussion}

The fertilizer Exactyon AG 18:5:13 gave significantly higher accumulated nut yield than the control treatment in the Moimenta trial, producing also significantly higher leaf $\mathrm{N}$ concentrations than the control. This fertilizer is the most concentrated in $\mathrm{N}$ and the one with the highest percentage of protected N. In the Moimenta experiment the leaf $\mathrm{N}$ concentrations in the control treatment were below the sufficiency range established for this species, whereas in the treatment Exactyon AG 18:5:13 the values were within the sufficiency range. Previous evidence for the importance of $\mathrm{N}$ fertilization in chestnut tree nutrition has already been reported (Arrobas et al. 2018). Other fruit tree crops grown in the region in similar shallow soils and in rainfed conditions usually also respond to $\mathrm{N}$ application, such as olive (Rodrigues et al. 2011) or almond (Arrobas et al. 2019). In Meixedo, no significant differences in nut production were found among treatments. Leaf $\mathrm{N}$ concentrations in the treatment Exactyon AG

Table 3 Average range of concentrations of nutrients in nuts. Pooled data of local, treatment, and year

\begin{tabular}{|c|c|c|c|c|c|c|c|c|c|c|}
\hline & \multicolumn{5}{|c|}{ Macronutrients ( $\mathrm{g} \mathrm{kg}^{-1}$ dry matter) } & \multicolumn{5}{|c|}{ Micronutrients ( $\mathrm{mg} \mathrm{kg}^{-1}$ dry matter) } \\
\hline & Nitrogen & Phosphorus & Potassium & Calcium & Magnesium & Boron & Copper & Iron & Zinc & Manganese \\
\hline Variation range & $8.9-11.1$ & $0.9-1.2$ & $5.5-8.2$ & $0.5-0.6$ & $0.5-0.7$ & $7.7-14.3$ & $6.7-10.1$ & $14.6-22.1$ & $15.4-23.7$ & $24.0-67.7$ \\
\hline
\end{tabular}


Fig. 3 Leaf N, P, and K concentrations in the field experiments of Moimenta and Meixedo. Double lines are the upper and lower limits of the sufficiency range. The results of ANOVA examination are as follows: ns, not significant; *,**, and ***, significant at $P<0.05$, $P<0.01$, and $P<0.001)$. Error bars are the mean confidence intervals
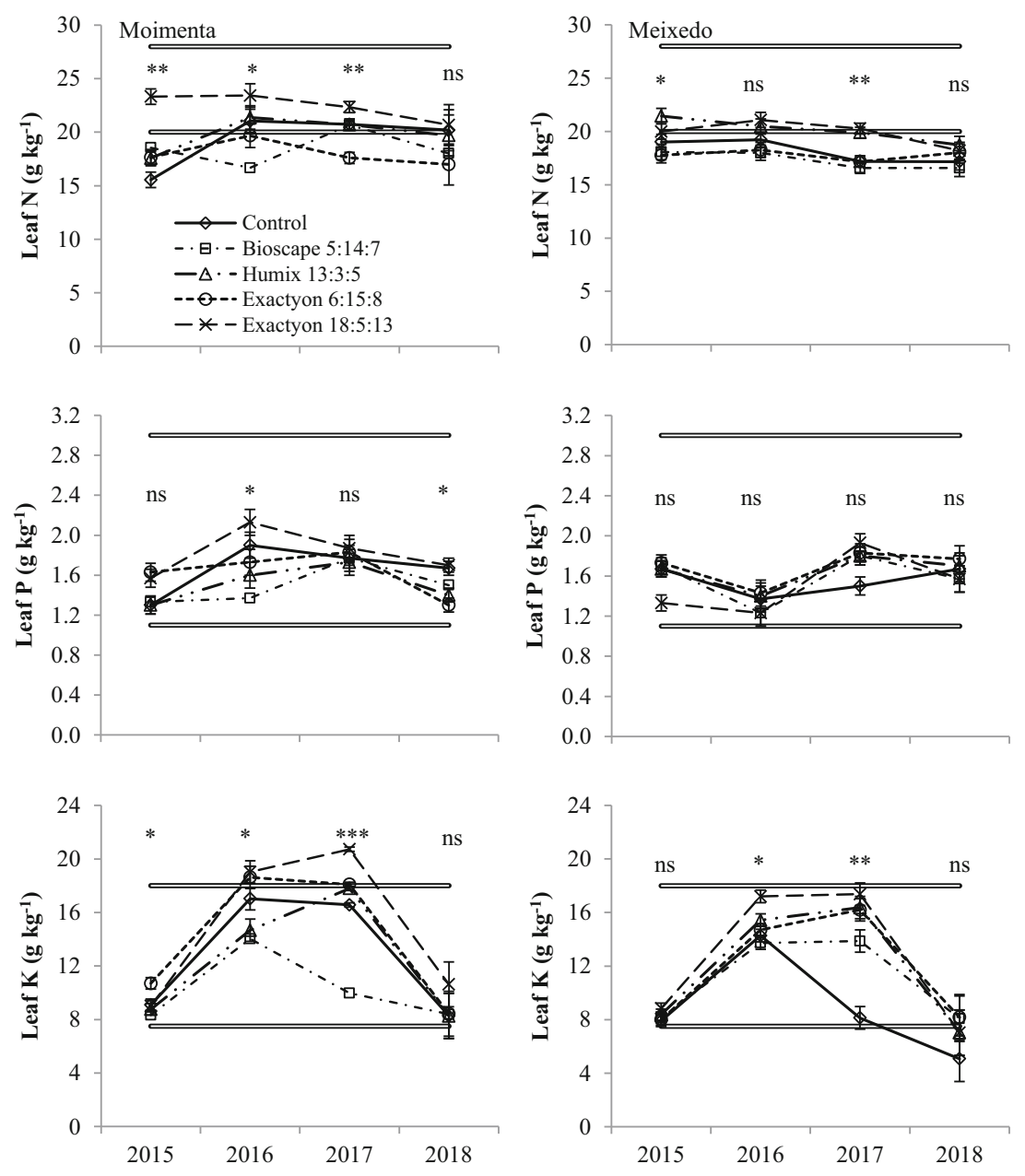

18:5:13 did not stand out so much from those of the control treatments, likely due to the competition for soil available $\mathrm{N}$ by the herbaceous vegetation. As previously reported for several other fruit species, cover crops tend to reduce fruit production if competition with trees for resources is high (Hoagland et al. 2008; Gucci et al. 2012; Silvestri et al. 2018). Thus, the use of $\mathrm{N}$ seems to be more efficient in tilled than in cover cropped orchards, at least in the short term (4 years) while the increasing pool of organic matter can lead to a negative balance between mineralization and immobilization (net immobilization).

The nutrients $\mathrm{P}$ and $\mathrm{K}$ seem to have had little effect on the trees. The levels of $\mathrm{P}$ and $\mathrm{K}$ in the soil were classified in the average and high ranges, respectively, at the beginning of the experiment, and the leaf levels persisted within the sufficiency ranges during the experimental period even in the control treatment. In chestnut, $\mathrm{P}$ and $\mathrm{K}$ removals in the fruits are usually low, varying respectively from $0.2-2.0$ to $2-$ $20 \mathrm{~kg} \mathrm{ha}^{-1}$ (Arrobas et al. 2018) and values within the same ranges were found in these experiments (Table 3 ). It seems that these soils are able to sustain the trees without or with little external applications of $\mathrm{P}$ and $\mathrm{K}$.
Although the soil of Moimenta is acid, the application of fertilizers containing high levels of $\mathrm{Ca}$ (Bioscape 5:14:7 and Exactyon AG 6:15:8) did not have a detectable effect on crop production. However, leaf $\mathrm{Ca}$ concentrations rose with the application of these fertilizers, namely in Moimenta where the $\mathrm{Ca}$ concentrations in the leaves of the control treatment were below the sufficiency range. In the Northeast of Portugal, the chestnut tree is cultivated at high altitudes (600 to $800 \mathrm{~m}$ ), where the soils are usually acidic, which makes it probable that chestnut is a species well adapted to acidity, as shown by Arrobas et al. (2017). Mg concentrations in the leaves were within the sufficiency range in all treatments at both sites.

Leaf B concentrations significantly increased in the trees fertilized with Exactyon AG 18:5:13, the fertilizer most concentrated in B (Table 2). In the Moimenta trial the leaf B concentrations were in the deficiency range in the control treatment and moved to the adequate range by the regular application of Exactyon AG 18:5:13. As previously mentioned, Exactyon AG 18:5:13 gave significantly higher nut yields than the control. Previous studies have highlighted the importance of B for chestnut (Portela et al. 2011, 2015) and 
Fig. 4 Leaf $\mathrm{Ca}, \mathrm{Mg}$, and $\mathrm{B}$ concentrations in the field experiments of Moimenta and Meixedo. Double lines are the upper and lower limits of the sufficiency range. The results of ANOVA examination are as follows: ns, not significant; *, **, and ***, significant at $P<0.05$, $P<0.01$, and $P<0.001$ ). Error bars are the mean confidence intervals
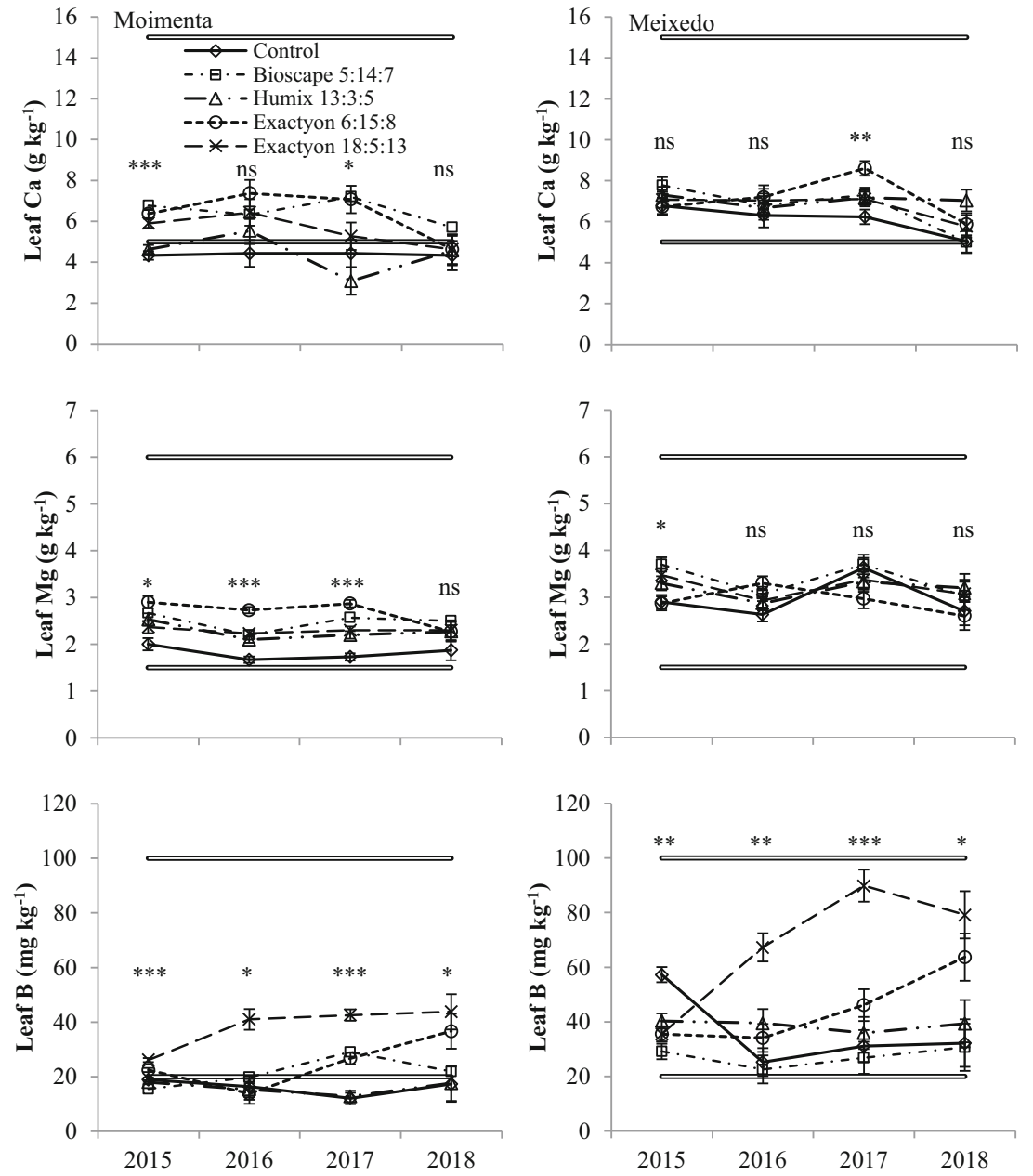

Table 4 Leaf concentrations of micronutrients iron, zinc, copper and manganese in 2015 and 2018 as a function of fertilizer treatments and site (Moi, Moimenta; and Mei, Meixedo)

\begin{tabular}{|c|c|c|c|c|c|c|c|}
\hline \multicolumn{2}{|l|}{ Iron } & \multicolumn{2}{|l|}{ Zinc } & \multicolumn{2}{|c|}{ Copper } & \multicolumn{2}{|c|}{ Manganese } \\
\hline $\begin{array}{l}\text { Moi } \\
\mathrm{mg} \mathrm{kg}^{-1}\end{array}$ & Mei & Moi & Mei & Moi & Mei & Moi & Mei \\
\hline
\end{tabular}

\begin{tabular}{|c|c|c|c|c|c|c|c|c|}
\hline \multicolumn{9}{|l|}{2015} \\
\hline Control & $133.1 \mathrm{a}$ & $133.3 b$ & $28.5 b$ & $20.2 b$ & $4.7 \mathrm{c}$ & $6.4 \mathrm{a}$ & $677.6 \mathrm{a}$ & $1724.0 \mathrm{bc}$ \\
\hline Bioscape 5:14:7 & $140.3 \mathrm{a}$ & $163.1 \mathrm{ab}$ & $35.5 \mathrm{ab}$ & $23.8 \mathrm{ab}$ & $4.2 \mathrm{c}$ & $6.5 \mathrm{a}$ & $708.1 \mathrm{a}$ & $1793.5 b c$ \\
\hline Humix 13:3:5 & $139.7 \mathrm{a}$ & $152.8 \mathrm{ab}$ & $30.9 \mathrm{ab}$ & $26.0 \mathrm{a}$ & $7.5 \mathrm{a}$ & $6.7 \mathrm{a}$ & $861.7 \mathrm{a}$ & $2318.3 b$ \\
\hline Exactyon 6:15:8 & $163.7 \mathrm{a}$ & $177.9 \mathrm{a}$ & $37.7 \mathrm{a}$ & $26.3 \mathrm{a}$ & $5.3 \mathrm{bc}$ & $5.9 \mathrm{a}$ & $873.2 \mathrm{a}$ & $3041.6 a$ \\
\hline Exactyon 18:5:13 & $163.7 \mathrm{a}$ & $189.4 \mathrm{a}$ & $30.7 \mathrm{ab}$ & $26.7 \mathrm{a}$ & 7.1ab & $5.5 \mathrm{a}$ & $870.0 \mathrm{a}$ & $1613.8 \mathrm{c}$ \\
\hline \multicolumn{9}{|l|}{2018} \\
\hline Control & $99.7 \mathrm{a}$ & $85.4 \mathrm{~b}$ & $29.5 \mathrm{a}$ & $25.4 \mathrm{a}$ & $5.2 \mathrm{a}$ & $7.2 \mathrm{a}$ & $639.8 \mathrm{a}$ & $2164.4 \mathrm{a}$ \\
\hline Bioscape 5:14:7 & $95.9 \mathrm{a}$ & $110.0 \mathrm{ab}$ & $29.2 \mathrm{a}$ & $22.7 \mathrm{a}$ & $5.5 \mathrm{a}$ & $7.2 \mathrm{a}$ & $989.1 \mathrm{a}$ & $1616.9 \mathrm{a}$ \\
\hline Humix 13:3:5 & $91.7 \mathrm{a}$ & $102.1 \mathrm{ab}$ & $27.2 \mathrm{a}$ & $31.4 \mathrm{a}$ & $5.8 \mathrm{a}$ & $14.2 \mathrm{a}$ & $799.6 \mathrm{a}$ & $3419.9 a$ \\
\hline Exactyon 6:15:8 & $100.3 \mathrm{a}$ & $104.1 \mathrm{ab}$ & $29.2 \mathrm{a}$ & $34.9 \mathrm{a}$ & $5.4 \mathrm{a}$ & $7.8 \mathrm{a}$ & $591.7 \mathrm{a}$ & $2915.3 a$ \\
\hline Exactyon 18:5:13 & $112.0 \mathrm{a}$ & $114.6 \mathrm{a}$ & $35.2 \mathrm{a}$ & $26.6 \mathrm{a}$ & $6.2 \mathrm{a}$ & $7.1 \mathrm{a}$ & $721.5 \mathrm{a}$ & $2059.9 a$ \\
\hline Sufficiency ranges & $15-300$ & & $15-75$ & & $4-40$ & & $100-2000$ & \\
\hline
\end{tabular}

In columns, separated by year, means followed by the same letter are not significantly different by Tukey HSD test $(\alpha=0.05)$ 
Table 5 Soil organic carbon from samples taken at the end of the field experiments in three soil layers

\begin{tabular}{|c|c|c|c|c|c|c|}
\hline & \multicolumn{3}{|l|}{ Moimenta } & \multicolumn{3}{|l|}{ Meixedo } \\
\hline & $\begin{array}{l}0-0.1 \mathrm{~m} \\
\mathrm{~g} \mathrm{~kg}^{-1}\end{array}$ & $0.1-0.2 \mathrm{~m}$ & $0.2-0.3 \mathrm{~m}$ & $0-0.1 \mathrm{~m}$ & $0.1-0.2 \mathrm{~m}$ & $0.2-0.3 \mathrm{~m}$ \\
\hline Control & $13.0 \mathrm{a}$ & $12.3 \mathrm{a}$ & $8.6 \mathrm{a}$ & $15.8 \mathrm{~b}$ & $6.8 \mathrm{a}$ & $5.3 \mathrm{a}$ \\
\hline Bioscape 5:14:7 & $15.6 \mathrm{a}$ & $14.5 \mathrm{a}$ & $7.8 \mathrm{a}$ & $22.0 \mathrm{a}$ & $8.4 \mathrm{a}$ & $4.7 \mathrm{a}$ \\
\hline Humix 13:3:5 & $16.8 \mathrm{a}$ & $14.1 \mathrm{a}$ & $8.0 \mathrm{a}$ & $22.3 \mathrm{a}$ & $8.1 \mathrm{a}$ & $5.3 \mathrm{a}$ \\
\hline Exactyon 6:15:8 & $14.0 \mathrm{a}$ & $14.5 \mathrm{a}$ & $9.4 \mathrm{a}$ & $21.8 \mathrm{a}$ & $9.1 \mathrm{a}$ & $5.1 \mathrm{a}$ \\
\hline Exactyon 18:5:13 & $17.1 \mathrm{a}$ & $13.7 \mathrm{a}$ & $7.6 \mathrm{a}$ & $19.9 \mathrm{a}$ & $8.8 \mathrm{a}$ & $5.9 \mathrm{a}$ \\
\hline
\end{tabular}

In columns, means followed by the same letter are not significantly different by Tukey HSD test $(\alpha=0.05)$

several other dicot species (Liakopoulos et al. 2005; Soyergin 2010; Sarafi et al. 2018; Arrobas et al. 2019). This result also suggests that part of the increase in nut productivity might be due to the better $\mathrm{B}$ nutrition of the trees fertilized with Exactyon AG 18:5:13. In Meixedo, leaf B levels were never found in the deficiency range even in the control treatment, which may have prevented the manifestation of a significant $B$ effect on crop productivity.

Fertilization increased the soil organic matter content mainly in the surface layer. The fertilizers enhanced the growth of the herbaceous vegetation which increased the deposit of organic substrates in the soil. Eventually the soil benefited also from an increase in the fallen leaves due to the stimulus on canopy growth from the use of fertilizers. In Moimenta, the positive effect of the fertilizers was registered up to $0.2 \mathrm{~m}$ deep, due to the soil being tilled. In Meixedo it was particularly high in the surface $0-0.1-\mathrm{m}$ layer and with a greater difference to the sub-surface layers. It has been experimentally demonstrated from many orchards that organic matter in the soil increases in cover cropped plots (Marquez-Garcia et al. 2013; Montanaro et al. 2017; Torres et al. 2018).

Soil P levels showed a pattern somewhat similar to organic matter. In Moimenta, higher values were recorded in the 0 $0.1-\mathrm{m}$ and $0.1-0.2-\mathrm{m}$ layers in the fertilized treatments in comparison to the control. In Meixedo, $\mathrm{P}$ levels associated with fertilized treatments were particularly high only in the $0-0.1$ $\mathrm{m}$ layer, since the soil was not tilled. The result is due to the reduced mobility of $\mathrm{P}$ in the soil, and the effect has been registered in other similar experiments (Arrobas et al. 2017; Ferreira et al. 2018). The acid phosphatase activity was not very sensitive to the fertilizer treatments. Organic matter tends to increase the acid phosphatase activity while available mineral P in the soil tends to reduce it (Kitayama 2013; Zhang et al. 2014; Ferreira et al. 2018). In this study, the higher

Table 6 Soil phosphorus $(\mathrm{P})$ as extracted by ammonium lactate and acid phosphatase activity from samples taken at the end of the field experiments at three soil layers

\begin{tabular}{|c|c|c|c|c|c|c|}
\hline & \multicolumn{3}{|c|}{ Moimenta } & \multicolumn{3}{|l|}{ Meixedo } \\
\hline & \multicolumn{6}{|c|}{ Soil layer (m) } \\
\hline & $0.0-0.1$ & $0.1-0.2$ & $0.2-0.3$ & $0.0-0.1$ & $0.1-0.2$ & $0.2-0.3$ \\
\hline \multicolumn{7}{|c|}{$\mathrm{P}$ extracted by ammonium lactate $\left(\mathrm{mg} \mathrm{kg}^{-1}, \mathrm{P}_{2} \mathrm{O}_{5}\right)$} \\
\hline Control & $157.3 \mathrm{c}$ & $124.5 b$ & $116.7 b$ & $171.2 \mathrm{~d}$ & $51.4 \mathrm{a}$ & $25.4 \mathrm{a}$ \\
\hline Bioscape 5:14:7 & $345.2 \mathrm{a}$ & $233.0 \mathrm{a}$ & $211.6 \mathrm{a}$ & $521.3 \mathrm{a}$ & $70.3 \mathrm{a}$ & $39.9 \mathrm{a}$ \\
\hline Humix 13:3:5 & $219.6 b c$ & $162.2 \mathrm{ab}$ & $150.4 \mathrm{ab}$ & $206.9 \mathrm{~cd}$ & $76.4 \mathrm{a}$ & $26.0 \mathrm{a}$ \\
\hline Exactyon 6:15:8 & $199.1 \mathrm{bc}$ & $140.7 \mathrm{ab}$ & $154.9 \mathrm{ab}$ & $416.6 \mathrm{ab}$ & $85.1 \mathrm{a}$ & $32.4 \mathrm{a}$ \\
\hline Exactyon 18:5:13 & $250.4 \mathrm{ab}$ & $186.4 \mathrm{a}$ & $228.9 \mathrm{a}$ & $285.5 b c$ & $62.4 \mathrm{a}$ & $44.2 \mathrm{a}$ \\
\hline \multicolumn{7}{|c|}{ Acid phosphatase activity (mg $p$-nitrophenol $\mathrm{kg}^{-1}$ soil $\mathrm{h}^{-1}$ ) } \\
\hline Control & $298.1 \mathrm{a}$ & $260.2 \mathrm{a}$ & $174.9 \mathrm{a}$ & $331.3 b$ & $241.6 b$ & $256.7 \mathrm{a}$ \\
\hline Bioscape 5:14:7 & $321.9 \mathrm{a}$ & $213.5 \mathrm{a}$ & $210.1 \mathrm{a}$ & $482.5 \mathrm{ab}$ & $391.8 \mathrm{a}$ & $183.9 \mathrm{a}$ \\
\hline Humix 13:3:5 & $328.5 \mathrm{a}$ & $290.1 \mathrm{a}$ & $251.3 \mathrm{a}$ & $567.7 \mathrm{a}$ & $212.9 \mathrm{~b}$ & $236.7 \mathrm{a}$ \\
\hline Exactyon 6:15:8 & $319.9 \mathrm{a}$ & $321.4 \mathrm{a}$ & $155.5 \mathrm{a}$ & $359.5 b$ & $310.9 \mathrm{ab}$ & $262.5 \mathrm{a}$ \\
\hline Exactyon 18:5:13 & $343.9 \mathrm{a}$ & $215.3 \mathrm{a}$ & $188.7 \mathrm{a}$ & $476.7 \mathrm{ab}$ & $409.3 \mathrm{a}$ & $305.6 \mathrm{a}$ \\
\hline
\end{tabular}

In columns, separated by index of soil available P, means followed by the same letter are not significantly different by Tukey HSD test $(\alpha=0.05)$ 
Table 7 Soil potassium (K) as extracted by ammonium lactate and ammonium acetate from samples taken at the end of the field experiments in three soil layers

\begin{tabular}{llllll} 
Moimenta & & & & Meixedo \\
\cline { 5 - 6 } Soil layer $(\mathrm{m})$ & & & & \\
\hline $0.0-0.1$ & $0.1-$ & $0.2-0.3$ & $0.0-0.1$ & $0.1-$ & $0.2-$ \\
& 0.2 & & & 0.2 & 0.3
\end{tabular}

\begin{tabular}{|c|c|c|c|c|c|c|}
\hline \multicolumn{7}{|c|}{$\mathrm{K}$ extracted by ammonium lactate $\left(\mathrm{mg} \mathrm{kg}^{-1}, \mathrm{~K}_{2} \mathrm{O}\right)$} \\
\hline Control & $225.0 \mathrm{~b}$ & $136.2 \mathrm{a}$ & $73.7 b$ & $231.7 \mathrm{~b}$ & $121.4 \mathrm{a}$ & $118.3 \mathrm{a}$ \\
\hline Bioscape 5:14:7 & $359.7 \mathrm{a}$ & $148.8 \mathrm{a}$ & 103.0ab & $322.6 \mathrm{a}$ & $142.1 \mathrm{a}$ & $109.7 \mathrm{a}$ \\
\hline Humix 13:3:5 & $292.0 \mathrm{ab}$ & $151.2 \mathrm{a}$ & $91.0 \mathrm{ab}$ & $277.0 \mathrm{ab}$ & $180.2 \mathrm{a}$ & $123.3 \mathrm{a}$ \\
\hline Exactyon 6:15:8 & $301.4 \mathrm{ab}$ & $172.2 \mathrm{a}$ & $104.0 \mathrm{ab}$ & $316.1 \mathrm{a}$ & $159.1 \mathrm{a}$ & $105.7 \mathrm{a}$ \\
\hline Exactyon 18:5:13 & $360.1 \mathrm{a}$ & $176.5 \mathrm{a}$ & $114.7 \mathrm{a}$ & $304.3 \mathrm{a}$ & $184.6 \mathrm{a}$ & $123.0 \mathrm{a}$ \\
\hline \multicolumn{7}{|c|}{$\mathrm{K}$ extracted by ammonium acetate $\left(\mathrm{cmol}+\mathrm{kg}^{-1}\right)$} \\
\hline Control & $0.40 \mathrm{a}$ & $0.24 \mathrm{a}$ & $0.20 \mathrm{a}$ & $0.72 b$ & $0.39 \mathrm{a}$ & $0.29 \mathrm{a}$ \\
\hline Bioscape 5:14:7 & $0.54 \mathrm{a}$ & $0.31 \mathrm{a}$ & $0.23 \mathrm{a}$ & $1.31 \mathrm{a}$ & $0.38 \mathrm{a}$ & $0.27 \mathrm{a}$ \\
\hline Humix 13:3:5 & $0.38 \mathrm{a}$ & $0.36 \mathrm{a}$ & $0.21 \mathrm{a}$ & $1.14 \mathrm{a}$ & $0.55 \mathrm{a}$ & $0.31 \mathrm{a}$ \\
\hline Exactyon 6:15:8 & $0.56 \mathrm{a}$ & $0.32 \mathrm{a}$ & $0.23 \mathrm{a}$ & $1.15 \mathrm{a}$ & $0.43 \mathrm{a}$ & $0.28 \mathrm{a}$ \\
\hline Exactyon 18:5:13 & $0.57 \mathrm{a}$ & $0.31 \mathrm{a}$ & $0.28 \mathrm{a}$ & $1.32 \mathrm{a}$ & $0.50 \mathrm{a}$ & $0.30 \mathrm{a}$ \\
\hline
\end{tabular}

In columns, separated method of extraction, means followed by the same letter are not significantly different by Tukey HSD test $(\alpha=0.05)$

organic matter content coincided with the higher levels of available $\mathrm{P}$ in the soil, which may have hindered the interpretation of the result.

$\mathrm{K}$ in the soil showed a dynamic similar to $\mathrm{P}$, but with faster mobility in depth, even in the non-tilled orchard. K, although having a positive charge with the possibility of being adsorbed in the clay-humic complexes or fixed in 2:1 clay minerals, is known to be more mobile in the soil than $P$ (Havlin et al. 2014). The ammonium lactate method appeared to be more sensitive to assess the availability of $\mathrm{K}$ in the soil than the ammonium acetate method.

Soil B levels were higher in the fertilized treatments providing more $\mathrm{B}$ in comparison to the control. In Meixedo, soil B levels in the treatment Exactyon AG
$18: 5: 13$, the most concentrated in B, were particularly high in the surface layer, likely due to the higher content of organic matter, which is usually associated with the retention of B in the soil (Gupta 2007; Havlin et al. 2014).

Overall, it appears that fertilizers have had a greater effect on soil properties and on tree nutritional status due to their nutrient content rather than to the nutrient protection mechanisms. Previous studies have shown that the use of slow- or controlled-release fertilizers has often given good results in containerized nursery plants (Oliet et al. 2004) or environments where nutrient management is particularly difficult, such as in rice (Wei et al. 2018), but in several field experiments it has not always been possible to record advantages of using fertilizers with slow-release mechanism compared with

Table 8 Soil boron (B) as extracted by hot water from samples taken at the end of the field experiments in three soil layers

\begin{tabular}{|c|c|c|c|c|c|c|}
\hline & \multicolumn{3}{|c|}{ Moimenta } & \multicolumn{3}{|l|}{ Meixedo } \\
\hline & \multicolumn{6}{|c|}{ Soil layer (m) } \\
\hline & $0.0-0.1$ & $0.1-0.2$ & $0.2-0.3$ & $0.0-0.1$ & $0.1-0.2$ & $0.2-0.3$ \\
\hline \multicolumn{7}{|c|}{ B extracted by hot water, azomethine- $\mathrm{H}\left(\mathrm{mg} \mathrm{kg}^{-1}\right)$} \\
\hline Control & $0.73 b$ & $0.72 b$ & $0.33 \mathrm{c}$ & $1.03 \mathrm{c}$ & $0.53 b$ & $0.41 \mathrm{c}$ \\
\hline Bioscape 5:14:7 & $1.07 \mathrm{ab}$ & $1.01 \mathrm{ab}$ & $0.74 b$ & $1.48 \mathrm{bc}$ & $0.61 b$ & $0.52 \mathrm{bc}$ \\
\hline Humix 13:3:5 & $0.92 \mathrm{ab}$ & $0.71 b$ & $0.31 \mathrm{c}$ & $1.83 \mathrm{bc}$ & $0.70 \mathrm{~b}$ & $0.62 \mathrm{bc}$ \\
\hline Exactyon 6:15:8 & $0.94 \mathrm{ab}$ & $0.97 \mathrm{ab}$ & $0.70 \mathrm{~b}$ & $2.09 \mathrm{~b}$ & $0.88 \mathrm{~b}$ & $0.97 \mathrm{ab}$ \\
\hline Exactyon 18:5:13 & $1.43 \mathrm{a}$ & $1.20 \mathrm{a}$ & $0.98 \mathrm{a}$ & $3.31 \mathrm{a}$ & $1.54 \mathrm{a}$ & $1.16 \mathrm{a}$ \\
\hline
\end{tabular}

In columns, means followed by the same letter are not significantly different by Tukey HSD test $(\alpha=0.05)$ 
traditional water-soluble fertilizers (Rodrigues et al. 2010; Arrobas et al. 2011).

\section{Conclusions}

The fertilizer most concentrated in $\mathrm{N}$ and $\mathrm{B}$ and the one with the highest percentage of $\mathrm{N}$ protected gave higher leaf $\mathrm{N}$ and $\mathrm{B}$ concentrations and nut yield, which highlights the importance of N and B in these agroecosystems.

Fertilization increased soil organic matter particularly in the surface layer of the cover cropped orchard, an aspect of great relevance to the sustainability of these agroecosystems.

There was not enough experimental evidence to suggest that organic materials and fertilizers with mechanisms for controlled-release provided per se major benefits to the trees in the four years of the trials.

The results suggest that long term studies should be performed to better clarify the benefits of using slow-release fertilizers in large trees such as chestnut. Meanwhile, farmers should be cautious about the use of fertilizers with mechanisms of nutrient protection if they are substantially more expensive than the conventional water-soluble fertilizers.

Funding Information This study received financial support from the Foundation for Science and Technology (FCT, Portugal) and FEDER under Programme PT2020 to CIMO (UID/AGR/00690/2015) and FEADER (The European Agricultural Fund for Rural Development) through the project CMP122 - PDR2020-101-030981 - EGIS, Estratégias para uma Gestão Integrada do Solo e da Água em Espécies Produtoras de Frutos Secos.

\section{Compliance with ethical standards}

Conflict of Interest The authors declare that they have no conflict of interest.

\section{References}

Alef K, Nannipieri P, Trazar-Cepeda C (1995) Phosphatase activity. In: Alef K, Nannipieri P (eds) Methods in applied soil microbiology and biochemistry. Academic Press, San Diego, pp 214-215

Álvarez-Álvarez P, Díaz-Varela E, Cámara-Obregón A, Afif-Khouri E (2010) Relating growth and nutrition to site factors in young chestnut plantations established on agricultural and forest land in northern Spain. Agrofor Syst 79:291-301

Arrobas M, Parada MJ, Magalhães P, Rodrigues MA (2011) Nitrogen-use efficiency and economic efficiency of slow-release $\mathrm{N}$ fertilisers applied to irrigated turfs in a Mediterranean environment. Nutr Cycl Agroecosyst 89:329-339

Arrobas M, Afonso S, Ferreira IQ, Moutinho-Pereira JM, Correia CM, Rodrigues MA (2017) Liming and application of nitrogen, phosphorus, potassium and boron on a young plantation of chestnut. Turk $\mathrm{J}$ Agric For 41:441-451

Arrobas M, Afonso S, Rodrigues MA (2018) Diagnosing the nutritional condition of chestnut groves by soil and leaf analyses. Sci Hortic 228:113-121
Arrobas M, Ribeiro AC, Barreales D, Pereira E, Rodrigues MA (2019) Soil and foliar nitrogen and boron fertilization of almond trees grown under rainfed conditions. Eur J Agron 106:39-48

Borges O, Gonçalves B, Soeiro JL (2008) Nutritional quality of chestnut (Castanea sativa Mill.) cultivars from Portugal. Food Chem 106: 976-984

Crame W, Guiot J, Fader M, Garrabou J, Gattuso JP, Iglesias A, Lange MA, Lionello P, Llasat MC, Paz S, Peñuelas J, Snoussi M, Toreti A, Tsimplis MN, Xoplaki E (2018) Climate change and interconnected risks to sustainable development in the Mediterranean. Nat Clim Chang 8:972-980

Echegaray N, Gomez B, Barba FJ, Franco D, Estevez M, Carballo J, Marszałek K, Lorenzo JM (2018) Chestnuts and by-products as source of natural antioxidants in meat and meat products: a review. Trends Food Sci Technol 82:110-121

Fernández-Escobar R (2017) Fertilization. In: Barranco D, FernándezEscobar R, Rallo L (eds) El Cultivo del Olivo, 7th edn. MundiPrensa, Madrid, pp 419-460

Ferreira IQ, Rodrigues MA, Moutinho-Pereira JM, Correia C, Arrobas M (2018) Olive tree response to applied phosphorus in field and pot experiments. Scientia Horticulturae Sci Hort 234:236-244

Gençer NS, Mert C (2019) Studies on the gall characteristics of Dryocosmus kuriphilus in chestnut genotypes in Yalova and Bursa provinces of Turkey. Not Bot Hort Agrobo 47(1):177-182

Gouveia ME, Choupina A, Coelho V, Monte E, Hermosa R, Abreu CG (2005) Diagnosis of ink disease of chestnut by molecular identification of associated Phytophthora species. Acta Hortic 639:585-589

Gucci R, Caruso G, Bertolla C, Urbani S, Taticchi A, Esposto S, Servili M, Sifola MI, Pellegrini S, Pagliai M, Vignozzi N (2012) Changes of soil properties and tree performance induced by soil management in a high-density olive orchard. Eur J Agron 41:18-27

Gupta UC (2007) Boron. In: Barker AV, Pilbeam DJ (eds) Handbook of plant nutrition. CRC, pp 241-277

Havlin JL, Tisdale SL, Nelson WL, Beaton JD (2014) Soil fertility and fertilizers, an introduction to nutrient management, 8 th edn. Pearson, Boston

Hoagland L, Carpenter-Boggs L, Granatstein D, Mazzola M, Smith J, Peryea F, Reganold JP (2008) Orchard floor management effects on nitrogen fertility and soil biological activity in a newly established organic apple orchard. Biol Fertil Soils 45:11-18

Houba VJG, van der Lee JJ, Novozamsky I (1997) Soil analysis procedures. Landbouwuniversiteit Wagningen, Other Procedures

Kitayama K (2013) The activities of soil and root acid phosphatase in the nine tropical rain forests that differ in phosphorus availability on Mount Kinabalu, Borneo. Plant Soil 367:215-224

Liakopoulos G, Stavrianakou S, Filippou M, Fasseas C, Tsadilas C, Drossopoulos I, Karabourniotis G (2005) Boron remobilization at low boron supply in olive (Olea europaea) in relation to leaf and phloem mannitol concentrations. Tree Physiol 25:157-165

Marquez-Garcia F, Gonzalez-Sanchez EJ, Castro-Garcia S, OrdoñezFernandez R (2013) Improvement of soil carbon sink by cover crops in olive orchards under semiarid conditions. Influence of the type of soil and weed. Span J Agric Res 11(2):335-346

Martins A, Marques G, Borges O, Portela E, Lousada J, Raimundo F, Madeira M (2011) Management of chestnut plantations for a multifunctional land use under Mediterranean conditions: effects on productivity and sustainability. Agrofor Syst 81:175-189

Maurel M, Robin C, Capron G, Desprez-Loustau M-L (2001) Effects of root damage associated with Phytophthora cinnamomi on water relations, biomass accumulation, mineral nutrition and vulnerability to water deficit of Æve oak and chestnut species. For Path 31:353-369

Montanaro G, Xiloyannis C, Nuzzo V, Dichio B (2017) Orchard management, soil organic carbon and ecosystem services in Mediterranean fruit tree crops. Sci Hortic 217:92-101 
Murolo S, Concas J, Romanazzi G (2019) Use of biocontrol agents as potential tools in the management of chestnut blight. Biol Control 132:102-109

Oliet J, Planelles R, Segura ML, Artero F, Jacobs DF (2004) Mineral nutrition and growth containerized Pinus halepensis seedlings under controlled-release fertilizer. Sci Hortic 103:113-129

Olk, DC 2008 Organic forms of soil nitrogen. In: J. S. Schepers, W. R. Raun (Eds.), Nitrogen in agricultural systems. Agronomy Monograph n. ${ }^{\circ}$ 49. ASA, CSSA, SSSA, Madison, WI, USA, pp: $57-100$

Portela E, Ferreira-Cardoso JV, Louzada JL (2011) Boron application on a chestnut orchard: effect on yield and quality of nuts. J Plant Nutr 34:1245-1253

Portela E, Ferreira-Cardoso J, Louzada J, Gomes-Laranjo J (2015) Assessment of boron application in chestnuts: nut yield and quality. J Plant Nutr 38:973-987

Rodrigues MA, Santos H, Ruivo S, Arrobas M (2010) Slow-release N fertilisers are not an alternative to urea for fertilisation of autumngrown tall cabbage. Eur J Agron 32(2):137-143

Rodrigues MA, Pavão F, Lopes JI, Gomes V, Arrobas M, MoutinhoPereira J, Ruivo S, Cabanas JE, Correia CM (2011) Olive yields and tree nutritional status during a four year period without nitrogen and boron fertilization. Commun Soil Sci Plant Anal 42(7):803-814

Sarafi E, Siomos A, Tsouvaltzis T, Chatzissavvidis I, C. (2018) The influence of boron on pepper plants nutritional status and nutrient efficiency. J Soil Sci Plant Nutr 18(3):653-667
Silvestri N, Giannini V, Antichi D (2018) Intercropping cover crops with a poplar short rotation coppice: effects on nutrient uptake and biomass production. Ital $\mathrm{J}$ Agron 13:934

Soyergin S (2010) Effects of soil and leaf treatments to eliminate boron deficiency in olives. Commun Soil Sci Plant Anal 41:2004-2010

Torres MR-R, Ordóñez-Fernández R, Giráldez JV, Márquez-García J, Laguna A, Carbonell-Bojollo R (2018) Efficiency of four different seeded plants and native vegetation as cover crops in the control of soil and carbon losses by water erosion in olive orchards. Land Degrad Dev 29:2278-2290

Trenkel M (2010) Slow- and controlled-release and stabilized fertilizers: an option for enhancing nutrient efficiency in agriculture, 2nd edn. International Fertilizer Industry Association, Paris

Wei H, Chen Z, Xing Z, Zhou L, Liu Q, Zhang Z, Jiang Y, Hu Y, Zhu J, Cui P, Dai Q, Zhang H (2018) Effects of slow or controlled release fertilizer types and fertilization modes on yield and quality of rice. J Integr Agric 17(10):2222-2234

Zhang G, Chen Z, Zhang A, Chen L, Wu Z, Ma X (2014) Phosphorus composition and phosphatase activities in soils affected by longterm application of pig manure and inorganic fertilizers. Commun Soil Sci Plant Anal 45:1866-1876

Zhang W, Liang Z, He X, Wang X, Shi X, Zou C, Chen X (2019) The effects of controlled release urea on maize productivity and reactive nitrogen losses: a meta-analysis. Environ Pollut 246:559-565

Publisher's Note Springer Nature remains neutral with regard to jurisdictional claims in published maps and institutional affiliations. 